\title{
Analisis Kadar Kreatinin Serum Sebelum dan Setelah Terapi Tenovofir pada Penyandang HIV di RS Dr. M. Djamil Padang Periode 2012-2013
}

Regina Ivanovna, Efrida, Roza Kurniati

\begin{abstract}
Abstrak
Penyakit ginjal merupakan penyebab kematian nonAIDS paling tinggi pada penyandang HIV. Penggunaan regimen anti- retroviral diselidiki memiliki kontribusi terhadap kejadian penyakit ginjal. Disfungsi tubulus ditemukan pada penyandang HIV dengan terapi tenofovir. Pemeriksaan kreatinin digunakan untuk skrining kerusakan ginjal. Tujuan penelitian ini adalah untuk mengetahui perbedaan kadar kreatinin sebelum dan setelah terapi tenofovir. Telah dilakukan penelitian secara kohort retrospektif terhadap penyandang HIV dengan terapi tenofovir di RS dr. M. Djamil Padang periode 2012-2013. Dilakukan pemeriksaan kreatinin serum sebelum dan setelah terapi tenofovir dengan metode Jaffe. Data kadar kreatinin serum didapatkan melalui rekam medik. Hasil perbedaan rata-rata kadar kreatinin serum sebelum dan setelah terapi tenofovir dianalisis menggunakan uji T berpasangan. Sebanyak 18 subyek penelitian dipilih dari jumlah total 652 penyandang HIV rawat inap dan rawat jalan. Sebanyak 196 penyandang HIV memakai terapi tenofovir (30\%). Rentang lama pemberian terapi tenofovir adalah 2-57 minggu. Pada hasil penelitian, didapatkan perbedaan rata-rata kadar kreatinin serum yang bermakna sebelum dan setelah terapi tenofovir sebesar $0,7 \pm 0,2 \mathrm{mg} / \mathrm{dLdan} 0,9 \pm 0,5 \mathrm{mg} / \mathrm{dL}(\mathrm{P}<0,05)$. Dapat disimpulkan bahwa terdapat peningkatan kreatinin serum setelah terapi tenofovir pada penyandang HIV.
\end{abstract}

Kata kunci: HIV, tenofovir, kreatinin serum

\begin{abstract}
Kidney disease is the highest nonAIDS related mortality among HIV patients. The use of antiretroviral therapy is investigated to contribute in kidney disease. Tubular dysfunction is found in HIV patients with tenofovir therapy. Creatinine test is used to screen kidney dysfunction. The aim of this study was to determine the mean difference of serum creatinine level before and after tenofovir administration.A cohort retrospective research was carried out in DR..M. Djamil Hospital upon HIV patients with tenofovir within 2012-2013. Serum creatinine test was conducted before and after administration of tenofovir with automatic machine and Jaffe reaction. The result of mean difference of serum creatinine before and after administration of tenofovir is analised by paired $T$ test.Eighteen research subjects is determined from total amount of in and out patient. A total of 196 patients were administered with tenofovir (30\%). The range of tenofovir administration was between 2-57 weeks. From the research, obtained a significant mean difference before $(0,7 \pm 0,2 \mathrm{mg} / \mathrm{dL})$ and after $(0,9 \pm 0,5 \mathrm{mg} / \mathrm{dL})$ administration of tenofovir $(P<0,05)$. The conclusion of this study is there is increasing of serum creatinine level before and after administration of tenofovir.
\end{abstract}

Keywords: HIV, tenofovir, serum creatinine

Affiliasi penulis : Fakultas Kedokteran Universitas Andalas Korespondensi : Regina Ivanovna, email: reginaivanovna@gmail.com, Telp: +6281387212039

\section{PENDAHULUAN}

Penggunaan regimen antiretroviral pada penyandang HIV memiliki kontribusi terhadap kejadian penyakit ginjal. Gangguan ginjal terlihat pada penggunaan tenofovir dan indinavir. ${ }^{1}$ Tenofovir disoproxil fumarate (TDF) atau tenofovir adalah antiretroviral yang digunakan dalam regimen terapi ARV. Tenofovir termasuk golongan nucleotide reverse transcriptase inhibitor (NRTI) yang sangat efektif dalam terapi ARV HIV dan hepatitis B.

Tenofovir digunakan sebagai terapi lini pertama terapi HIV dikombinasikan dengan lamivudine dan efavirenz/nevirapine. American Academy of HIV Medicine dan European AIDS Clinical Society juga merekomendasikan tenofovir sebagai terapi lini pertama infeksi $\mathrm{HIV}^{2}$ Tenofovir dikonsumsi sekali perhari dengan dosis tetap (fixed dose) sebanyak 300 $\mathrm{mg}^{3}$

Efek samping tenofovir adalah penurunan laju filtrasi glomerulus (LFG) dan sindrom Fanconi. Tenofovir juga memiliki potensi toksisitas renal dan disfungsi tubular. ${ }^{4}$ Beberapa penelitian telah menguji hubungan paparan tenofovir dengan fungsi ginjal. Fungsi ginjal dapat ditentukan dengan mengukur kadar kreatinin serum, klirens kreatinin, dan estimasi LFG. $^{4}$

Rodriguez menyatakan tenofovir berhubungan dengan disfungsi tubulus ginjal. ${ }^{1}$ Bagian ginjal yang paling banyak dipengaruhi tenofovir adalah tubulus proksimal. Toksisitas tenofovir bergantung pada dosis dan waktu (dose and time dependent), terutama kadar intrarenal yang menyebabkan kerusakan tubulus.

Gagal ginjal akut dapat terjadi pada penyandang 
HIV dengan terapi tenofovir., ${ }^{5,6}$ Tenofovir dapat menyebabkan gagal ginjal akut setelah dua minggu pemakaian. ${ }^{6,7}$ Kadar kreatinin serum meningkat dari $0,8 \mathrm{mg} / \mathrm{dL}$ menjadi $2,6 \mathrm{mg} / \mathrm{dL}$ setelah dua minggu terapi. $^{7} \quad$ Penyandang dengan terapi tenofovir disarankan melakukan pemeriksaan kadar kreatinin serum tiap 3 bulan. $^{4}$

Disfungsi tubulus distalis juga ditemukan pada penyandang HIV dengan terapi tenofovir. Temuan pada penyandang HIV dengan TDF associated renal tubular toxicity adalah hipofosfatemia, nyeri tulang, kenaikan rasio protein kreatinin urine, dan peningkatan kadar kreatinin serum. ${ }^{1}$

Kreatinin merupakan produk akhir nonprotein dari metabolisme kreatinin. Seluruh kreatinin diekskresikan lewat ginjal. Kreatinin berhubungan langsung dengan fungsi ekskretorik ginjal. Pemeriksaan kreatinin digunakan untuk memperkirakan LFG dan untuk skrining kerusakan ginjal. $^{8,9}$

Penelitian mengenai efek tenofovir terhadap fungsi ginjal belum pernah dilakukan di RS DR. M. Djamil Padang. Penulis tertarik untuk melakukan penelitian mengenai analisis perbedaan kadar kreatinin serum sebelum dan setelah terapi tenofovir di RS DR. M. Djamil Padang periode 2012-2013.

\section{METODE}

Jenis penelitian ini adalah studi analitik dengan metode kohort retrospektif. Populasi penelitian merupakan pasien terdiagnosis HIV yang menjalani rawat inap dan rawat jalan dengan terapi tenofovir di RS Dr. M. Djamil periode 2012 - 2013 (data sekunder). Subjek penelitian diambil menggunakan metode total sampling. Kriteria inklusi penelitian ini adalah penyandang HIV dengan terapi tenofovir yang menjalani rawat inap dan berobat di Poliklinik VCT dengan pemeriksaan kreatinin serum sebelum dan setelah terapi tenofovir minimal dua minggu dan kreatinin serum normal sebelum memulai terapi tenofovir. Kriteria eksklusi penelitian ini yaitu riwayat atau sedang memakai obat nefrotoksik golongan aminoglikosida, diabetes melitus, protein urine positif secara makroskopis sebelum terapi tenofovir, menggunakan ARV golongan protease inhibitor, dan menggunakan didanosine dan ritonavir. Seluruh data diambil dari data rekam medik.

Variabel independen penelitian ini adalah kadar kreatinin serum, sementara variabel dependen penelitian ini adalah terapi tenofovir.

Setelah data dikumpulkan, dilakukan pemilihan subyek penelitian berdasarkan kriteria inklusi dan eksklusi. Selanjutnya, subyek penelitian dibagi menjadi dua kelompok, yaitu kadar kreatinin serum sebelum terapi tenofovir dan kadar kreatinin serum setelah terapi tenofovir. Data selanjutnya dianalisis menggunakan SPSS 15.0 dengan uji $\mathrm{T}$ untuk mengetahui perbedaan rata-rata kedua kelompok penelitian.
HASIL

Telah dilakukan penelitian secara retrospektif terhadap penyandang HIV dengan terapi tenofovir di RS DR. M. Djamil Padang periode 2012-2013. Terdapat 652 penyandang HIV selama periode 20122013. Penyandang HIV rawat inap dan rawat jalan tahun 2012 sebanyak 136 dan 189 penyandang. Selanjutnya, penyandang HIV rawat inap dan rawat jalan sebanyak 178 dan 149 penyandang pada tahun 2013. Selama periode 2012-2013, sebanyak 196 penyandang HIV mendapat terapi kombinasi ARV dengan tenofovir (30\%).Terdapat 18 penyandang HIV yang memenuhi kriteria sebagai subyek penelitian.

Tabel 1. Karakteristik Umum Subyek Penelitian

\begin{tabular}{lcc}
\hline \multicolumn{1}{c}{ Karakteristik } & $\mathbf{n}(\%)$ & rerata \pm SD \\
\hline JenisKelamin & $10(56)$ & \\
Laki-laki & $8(44)$ & \\
Perempuan & & $34 \pm 8,3$ \\
Umur (tahun) & & $15 \pm 14,3$ \\
LamaTerapi (minggu) & & \\
\hline
\end{tabular}

Berdasarkan tabel 1, rata-rata umur subyek penelitian adalah 34 tahun. Penyandang HIV laki-laki (56\%) lebih banyak daripada penyandang perempuan (44\%). Rata-rata lama terapi subyek penelitian sejak mulai terapi tenofovir sampai pemeriksaan kreatinin kedua adalah 15 minggu.

Durasi pemakaian tenofovir dalam minggu yang digambarkan pada tabel 2 berikut ini:

Tabel 2. Lama Pemberian Tenofovir dan Jumlah Subyek Penelitian

\begin{tabular}{lcc}
\hline JenisTerapi & $\begin{array}{c}\text { Lama Pemberian } \\
\text { (minggu) }\end{array}$ & $\mathbf{n}(\%)$ \\
\hline Tenofovir & $2-14$ & $10(55)$ \\
& $15-27$ & $6(33)$ \\
& $28-40$ & $1(6)$ \\
& $41-53$ & - \\
& $54-65$ & $1(56)$ \\
\hline Total & & 18 \\
\hline
\end{tabular}

Durasi pemakaian tenofovir dibagi masingmasing 12 minggu dalam lima kelompok, yaitu penyandang HIV dengan terapi tenofovir 2-14 minggu, 15-27 minggu, 28-40 minggu, 41-53 minggu, dan 5465 minggu. Kelompok durasi dengan subyek penelitian paling banyak adalah kelompok lama terapi 2-14 minggu (55\%). Sementara itu, kelompok dengan durasi pemberian tenofovir paling lama adalah kelompok 54-65 minggu, yaitu 5\%.

Tabel 3. Kadar Kreatinin Serum

\begin{tabular}{lccc}
\hline \multicolumn{1}{c}{ Jenis } & \multicolumn{2}{c}{ Kadar Kreatinin Serum } & P \\
\cline { 2 - 3 } & SebelumTerapi & SesudahTerapi & \\
\hline $\begin{array}{l}\text { Kreatinin } \\
\begin{array}{l}\text { Rerata } \pm \text { SD } \\
(\mathrm{mg} / \mathrm{dL})\end{array}\end{array}$ & $0,7 \pm 0,2$ & $0,9 \pm 0,5$ & 0,001 \\
\hline
\end{tabular}


Berdasarkan tabel 3, rata-rata kadar kreatinin sebelum terapi tenofovir adalah $0,7 \mathrm{mg} / \mathrm{dL}$. Kadar terendah kreatinin serum adalah $0,3 \mathrm{mg} / \mathrm{dL}$ dan kadar tertinggi setelah terapi, yaitu $1,1 \mathrm{mg} / \mathrm{dL}$. Selanjutnya, rata-rata kadar kreatinin serum setelah terapi tenofovir adalah $0,9 \mathrm{mg} / \mathrm{dL}$. Kadar terendah kreatinin serum adalah $0,4 \mathrm{mg} / \mathrm{dL}$ dan kadar maksimum kreatinin 2,4 $\mathrm{mg} / \mathrm{dL}$.

Data hasil observasi menyebutkan terdapat penyandang yang mengalami peningkatan, penurunan, dan kadar kreatinin serum tetap setelah terapi tenofovir. Subyek yang mengalami peningkatan kreatinin serum, yaitu 11 penyandang (rerata $=0,4$ $\mathrm{mg} / \mathrm{dL}$ ). Penyandang dengan penurunan kadar kreatinin serum sebanyak 4 penyandang (rerata $=-0,1$ $\mathrm{mg} / \mathrm{dL}$ ) dan kadar kreatinin serum tetap sebanyak 3 penyandang.

Rata-rata kadar kreatinin serum berdasarkan lama terapi tenofovir dijelaskan pada tabel 4 berikut ini:

Tabel 4. Rata-rata Perbedaan Kadar Kreatinin Serum Berdasarkan Lama Terapi

\begin{tabular}{cc}
\hline $\begin{array}{c}\text { Lama Terapi } \\
\text { (minggu) }\end{array}$ & Rerata \pm SD (mg/dL) \\
\hline $2-14$ & $0,3 \pm 0,6$ \\
$15-27$ & $0 \pm 0,1$ \\
$28-40$ & 0,3 \\
$41-53$ & - \\
$54-65$ & 0,7 \\
\hline
\end{tabular}

Rata-rata perbedaan kreatinin paling besar ditemukan pada kelompok durasi terapi 54-65 minggu $(0,7 \mathrm{mg} / \mathrm{dL})$, selanjutnya diikuti kelompok durasi $2-14$ minggu (0,3 mg/dL) dan kelompok $28-40$ minggu $(0,3$ $\mathrm{mg} / \mathrm{dL}$ ). Kelompok lama terapi 14-28 minggu mengalami rata-rata perbedaan kadar kreatinin tetap.

Ditemukan penyandang dengan peningkatan, penurunan, dan kadar kreatinin serum tetap. Terdapat 10 subyek penelitian dengan durasi terapi 2-14 minggu. Peningkatan kadar kreatinin serum ditemukan pada 6 penyandang (rerata=0,6 $\mathrm{mg} / \mathrm{dL}$ ). Penurunan ditemukan pada1 penyandang (rerata $=0,2 \mathrm{mg} / \mathrm{dL}$ ) dan 2 orang penyandang memiliki kadar kreatinin serum tetap.

Subyek dengan lama terapi 15-27 minggu sebanyak 6 penyandang. Terdapat penyandang dengan kadar kreatinin serum naik (3 penyandang, rerata $=0,1 \mathrm{mg} / \mathrm{dL}$ ) dan kadar kreatinin serum turun (3 penyandang, rerata $=0,1 \mathrm{mg} / \mathrm{dL}$ ). Terdapat satu penyandang dengan peningkatan kadar kreatinin serum setelah pemakaian tenofovir 28-40 minggu (rerata $=0,2 \mathrm{mg} / \mathrm{dL}$ ). Selanjutnya, satu penyandang dengan lama terapi 54-65 minggu mengalami peningkatan kadar kreatinin serum sebesar 0,7 mg/dL.

Tabel 5. Rata-rata Perbedaan Kadar Kreatinin Serum BerdasarkanJenisKelamin

\begin{tabular}{lccc}
\hline \multicolumn{1}{c}{$\begin{array}{c}\text { Jenis } \\
\text { Kelamin }\end{array}$} & \multicolumn{2}{c}{ Kadar Kreatinin Serum } & $\mathbf{P}$ \\
\cline { 2 - 3 } & SebelumTerapi & SesudahTerapi & \\
\hline $\begin{array}{l}\text { Laki-laki } \\
\begin{array}{l}\text { Rerata } \pm \text { SD } \\
(\mathrm{mg} / \mathrm{dL})\end{array}\end{array}$ & $0,8 \pm 0,2$ & $1 \pm 0,4$ & 0,075 \\
$\begin{array}{l}\text { Perempuan } \\
\begin{array}{l}\text { Rerata } \pm \text { SD } \\
(\mathrm{mg} / \mathrm{dL})\end{array}\end{array}$ & $0,7 \pm 0,1$ & $0,8 \pm 0,2$ & 0,001 \\
\hline
\end{tabular}

Terdapat perbedaan nilai rata-rata kadar kreatinin serum pada laki-laki dan perempuan. Kadar normal kreatinin serum pada perempuan adalah 0,6$0,9 \mathrm{mg} / \mathrm{dL}$, sedangkan pada laki-laki adalah 0,8-1,2 $\mathrm{mg} / \mathrm{dL}$. Perbedaan rata-rata bermakna kadar kreatinin serum sebelum dan setelah terapi pada perempuan $(\mathrm{P}<0,05)$. Sementara itu, tidak terdapat perbedaan rata-rata bermakna kadar kreatinin serum sebelum dan setelah terapi tenofovir $(P>0,05)$.

\section{PEMBAHASAN}

\section{Karakteristik Umum Subyek Penelitian}

Berdasarkan penelitian yang dilakukan secara kohort retrospektif di RS DR. M. Djamil Padang terhadap penyandang HIV dengan terapi tenofovir, didapatkan 18 kasus yang memenuhi kriteria untuk dijadikan sebagai subyek penelitian. Subyek tersebut dibagi menjadi dua kelompok, yaitu kelompok kadar kreatinin sebelum terapi tenofovir dan kelompok kadar kreatinin setelah terapi tenofovir.

Sebanyak 18 subyek penelitian diobservasi. Rata-rata umur subyek penelitian adalah 34 tahun dengan jumlah subyek laki-laki sebanyak 10 (56\%) dan jumlah subyek perempuan sebanyak 8 (44\%). Rata-rata lama terapi dengan tenofovir adalah 15 minggu. Durasi pemakaian tenofovir dibagi dalam lima kelompok, yaitu kelompok yang mendapat terapi tenofovir 2-14 minggu (10 penyandang), 15-27 minggu (6 penyandang), 28-40 minggu (2 penyandang), 40-53 minggu (0 penyandang) dan 54-65 minggu (1 penyandang).

Rata-rata umur subyek penelitian Gerard dkk.adalah 41 tahun dengan proporsi penyandang laki-laki sebanyak $55 \% .{ }^{10}$ Rata-rata umur subyek penelitian Zimmerman dkk. adalah 45,5 tahun. Perbandingan penyandang laki-laki dan perempuan 3,5:1. ${ }^{11}$ Rata-rata umur penyandang HIV pada penelitian ini lebih kecil, yaitu 34 tahun (rentang 22-51 tahun). Subyek penelitian dengan jenis kelamin lakilaki lebih banyak (55\%), sesuai dengan penelitian Gerard dkk. dan Zimmerman dkk. ${ }^{10,11}$

\section{Kadar Kreatinin Serum}

Kadar kreatinin serum rata-rata penyandang HIV 
sebelum terapi tenofovir adalah 0,7 mg/dL. Kadar ratarata kreatinin serum penyandang HIV sebelum terapi penelitian lain sebesar $0,8 \mathrm{mg} / \mathrm{dL} .{ }^{10}$ Schaaf $\mathrm{dkk}$. mengobservasi penyandang dengan kadar kreatinin serum sebelum terapi $0,8 \mathrm{mg} / \mathrm{dL}^{10}$ Kadar kreatinin serum pada subyek penelitian ini lebih kecil $0,1 \mathrm{mg} / \mathrm{dL}$ dibandingkan dua penelitian lain.

Rata-rata kadar kreatinin serum setelah terapi tenofovir adalah $0,9 \pm 0,5 \mathrm{mg} / \mathrm{dL}$. Kadar kreatinin ratarata setelah terapi tenofovir pada studi oleh Gerard dkk. adalah 0,9 mg/dL. ${ }^{10}$ Studi Doungchalermwong dan Sungkanuparph menyimpulkan terdapat peningkatan kadar kreatinin serum setelah terapi tenofovir, yaitu $0,90 \pm 0,24 \mathrm{mg} / \mathrm{dL} .{ }^{12}$ Rata-rata kadar kreatinin serum pada penelitian ini dengan dua penelitian lain sama, yaitu $0,9 \mathrm{mg} / \mathrm{dL}$.

Uji normalitas data dilakukan tehadap dua kelompok data. Nilai distribusi normal didapat pada masing-masing kelompok data $\mathrm{P}=0,559$ dan $\mathrm{P}=0,512$ $(P>0,05)$. Studi Zimmerman menyimpulkan terdapat perbedaan rata-rata kadar kreatinin serum sebelum dan setelah terapi tenofovir pada penyandang HIV. Hal tersebut dibuktikan dengan peningkatan rata-rata kadar kreatinin serum dari $0,9 \mathrm{mg} / \mathrm{dL}$ menjadi 3,9 $\mathrm{mg} / \mathrm{dL} \quad(\mathrm{P}<0,05) \quad(2006)$. Pada penelitian ini, didapatkan peningkatan kadar kreatinin serum setelah pemakaian terapi tenofovir, yaitu dari $0,7 \mathrm{mg} / \mathrm{dL}$ menjadi $0,9 \mathrm{mg} / \mathrm{dL}$.

Secara statistik berdasarkan uji T berpasangan, didapatkan perbedaan bermakna antara kadar kreatinin serum sebelum dan setelah terapi tenofovir, dimana didapatkan nilai $P=0,001 \quad(P<0,05)$. Makna dari uji statistik tersebut adalah penyandang HIV dengan terapi tenofovir menunjukkan peningkatan bermakna kadar kreatinin serum sebelum dan setelah terapi tenofovir. Hasil penelitian ini sesuai dengan hasil penelitian Zimmerman dkk. ${ }^{11}$

Sampel penelitian dipilih dengan durasi pemakaian tenofovir minimal dua minggu. Hal ini sesuai dengan penelitian Pavie dan Krummer bahwa gagal ginjal akut dapat ditemukan pada penyandang HIV dengan terapi tenofovir pada dua minggu pertama inisiasi terapi. ${ }^{6,7}$

Durasi penerimaan regimen tenofovir dibagi berdasarkan rentang 12 minggu. Hal ini sesuai dengan Pedoman Nasional Tatalaksana Klinis ARVyang merekomendasikan pemeriksaan kreatinin serum setelah tiga bulan. ${ }^{4}$ Pada kelompok durasi pemakaian tenofovir 2-14 minggu (8 subyek), didapatkan penyandang dengan peningkatan kadar kreatinin serum sebanyak 6 orang (rerata $=0,6 \mathrm{mg} / \mathrm{dL}$ ). Pada kelompok tersebut juga didapatkan penyandang dengan penurunan kadar keratinin serum sebanyak 1 orang (rerata $=0,2 \mathrm{mg} / \mathrm{dL}$ ). Sementara itu, terdapat penyandang yang tidak ditemukan peningkatan atau penurunan kadar kreatinin serum setelah tenofovir (3 orang). Rata-rata lama terapi penyandang HIV pada penelitian ini adalah 15 minggu.

Studi Gerard dkk. membuktikan bahwa terdapat kerusakan ginjal pada penyandang dengan terapi tenofovir pada minggu keempat dan minggu kelima ${ }^{11}$. $\mathrm{Hal}$ tersebut dibuktikan dengan biopsi ginjal dan diperoleh hasil kerusakan tubulus ginjal yang disebabkan oleh tenofovir. ${ }^{10}$ Rata-rata kreatinin serum studi tersebut, pada minggu ke-8 terapi tenofovir adalah $0,9 \mathrm{mg} / \mathrm{dL} .{ }^{10}$ Temuan tersebut sama dengan rata-rata kreatinin serum pada subyek dengan terapi tenofovir 2-14 minggu (rerata $=0,9 \mathrm{mg} / \mathrm{dL}$ ).
Penyandang yang menerima terapi tenofovir dengan rentang durasi penerimaan 15-27 minggu sebanyak 6 orang. Dari 6 orang tersebut, sebanyak 3 orang mengalami peningkatan kreatinin serum (rerata $=0,1 \mathrm{mg} / \mathrm{dL}$ ). Sebanyak 3 orang subyek mengalami penurunan kreatinin serum (rerata $=0,1$ $\mathrm{mg} / \mathrm{dL})$.

Penyandang dengan durasi terapi 54-65 minggu mengalami kenaikan kadar kreatinin serum sebesar $0,7 \mathrm{mg} / \mathrm{dL}$. Kadar kreatinin sebelum terapi adalah 1,1 $\mathrm{mg} / \mathrm{dL}$ dan setelah terapi $1,8 \mathrm{mg} / \mathrm{dL}$. Hasil ini sejalan dengan penelitian Gerard dkk. dimana $8 \%$ penyandang dengan rata-rata terapi tenofovir selama 48 minggu mengalami peningkatan kadar kreatinin serum sebesar $<1,5 x$ batas normal atas (upper normal limit). ${ }^{10}$

Terdapat perbedaan rata-rata kadar kreatinin serum pada penyandang laki-laki dan perempuan). Kadar normal kreatinin serum pada perempuan adalah 0,6-0,9 $\mathrm{mg} / \mathrm{dL}$, sedangkan kadar kreatinin serum normal pada laki-laki adalah 0,8-1,2 mg/dL. Kadar kreatinin serum subyek perempuan sebelum terapi sebesar $0,7 \pm 0,1 \mathrm{mg} / \mathrm{dL}$ dan setelah terapi sebesar $0,8 \pm 0,2 \mathrm{mg} / \mathrm{dL}$. Terdapat perbedaan rata-rata bermakna, yaitu $0,001(P<0,05)$.

Pada subyek laki-laki, rerata kadar kreatinin serum sebelum terapi lebih besar dari perempuan, yaitu 0,8 $\pm 0,2 \mathrm{mg} / \mathrm{dL}$, sedangkan rerata kadar kreatinin serum setelah terapi sebesar $1 \pm 0,4 \mathrm{mg} / \mathrm{dL}$. Tidak didapatkan perbedaan rata-rata bermakna pada kelompok laki-laki $(P>0,05)$.

Berdasarkan hasil penelitian, terdapat dua penyandang dengan kadar kreatinin serum diatas normal, yaitu $1,8 \mathrm{mg} / \mathrm{dL}$. Tidak ditemukan penyandang yang mengalami gangguan ginjal akut, yaitu kenaikan kadar kreatinin serum $\geq 2,0 \times 5 \times$ nilai dasar atau penurunan LFG $\geq 50 \%$. $^{13}$

Peningkatan dan penurunan kadar kreatinin serum lazim ditemukan pada berbagai penelitian. Peningkatan ringan dalam batas normal atas adalah indikasi terjadi perubahan subklinis fungsi ginjal pada penyandang dengan kadar kreatinin serum basal normal. ${ }^{10}$ Menurut penelitian kohort lain, peningkatan kadar kreatinin serum $>0,5 \mathrm{mg} / \mathrm{dL}$ ditemukan pada $2,2 \%$ penyandang $\mathrm{HIV}^{2}{ }^{2}$

Penelitian Rodriguez-Novoa dkk.menyebutkan bahwa terdapat kerentanan khusus penyandang dengan terapi tenofovir sehingga mengalami disfungsi tubulus ginjal. ${ }^{14}$ Tenofovir mengalami klirens oleh ginjal melalui mekanisme filtrasi glomerular dan sekresi tubular aktif. Gen polimorfisme yang mengode transporter obat telah diidentifikasi, yaitu homozigot alel C pada posisi-24 pada gen ABCC22 yang sangat berkaitan dengan disfungsi tubulus ginjal. Penyandang dengan polimorfisme gen ABCC2-24C mengekskresi tenofovir dengan tidak efisien. Sebanyak 18\% penyandang HIV dengan terapi tenofovir pada penelitian tersebut mengalami disfungsi tubulus ginjal. Penyandang yang mendapat terapi tenofovir dengan kadar kreatinin serum tetap atau mengalami penurunan kadar diduga tidak memiliki kerentanan terhadap transporter tenofovir. ${ }^{14}$

Selain disebabkan oleh kerentanan gen pengode transporter tenofovir, peningkatan dan penurunan kadar kreatinin serum dapat disebabkan oleh efek antiretroviral (ARV). Penyandang HIV dengan terapi ARV dapat mengalami penurunan massa otot (muscle wasting). ${ }^{15} \mathrm{Hal}$ ini dapat menjadi dasar teori yang 
menunjang penurunan kadar kreatinin serum pada empat subyek penelitian yang diobservasi.

Tiga penyandang dengan kadar kreatinin serum tetap sebelum dan setelah terapi tenofovir dapat dijelaskan melalui dasar teori: 1. Penggunaan tenofovir adalah dose dependent ${ }^{15}$ sehingga pada kadar yang belum melewati batas, konsentrasi tenofovir intrarenal tidak akan terjadi gangguan tubulus; 2. Setiap individu memiliki kerentanan transporter tenofovir yang berbeda. Hal ini dapat menjelaskan munculan penyandang dengan terapi tenofovir yang berbeda.

Keterbatasan penelitian ini adalah penelitian ini tidak memerhatikan distrofi otot. Distrofi otot tidak dapat diobservasi dari rekam medik subyek penelitian. Selanjutnya, penelitian ini tidak memerhatikan infeksi oportunistik pada subyek penelitian. Sebanyak $60 \%$ subyek penelitian mengalami TB paru dupleks, 20\% mengalami toksoplasmosis serebri, dan $20 \%$ subyek penelitian mengalami syok sepsis. Selain itu, jumlah subyek yang sedikit tidak mewakili populasi penelitian ini. Dari 169 penyandang HIV yang mendapat terapi tenofovir, hanya 18 penyandang yang memenuhi kriteria sebagai subyek penelitian.

\section{SIMPULAN}

Terjadi peningkatan kreatinin serum pada penyandang HIV dengan terapi tenofovir.

\section{DAFTAR PUSTAKA}

1. Phair J, Patella, F. Renal disease in HIV Infected Individuals. Curr Opin HIV AIDS. 2011; 6(4):2859.

2. Andrew $\mathrm{MH}$, Hendry BM, Nitsch D, Connolly J. Tenofovir-associated kidney toxicity in HIVinfected patients: a review of the evidence. Am. J. Kidney Dis. 2011;57(5):773-80.

3. Louisa M, Setiabudy R. Antivirus. Dalam: Gunawan SG, editor. Farmakologi dan Terapi. Edisi ke-5. FK Ul: Jakarta; 2007. hlm. 651-9.

4. Kementrian Kesehatan Republik Indonesia, Pedoman nasional tatalaksana klinis infeksi HIV dan terapi antiretroviral pada orang dewasa. Kementrian Kesehatan RI: Jakarta; 2012. hlm. 37-42.

5. Berns JS, Kasbekar N. Highly Active Antiretroviral Therapy and the Kidney: An Update on Antiretroviral Medications for Nephrologist. Clin J Am Soc Nephrol. 2006;1:177-9.
6. Pavie J, Scemla A, Bouldouvre MA, Pillebout E, Verine $\mathrm{J}$, Moline JM. Acute renal failure in an hivinfected patient after only 2 weeks of Tenofovir based antiretroviral therapy. AIDS Patient Care STDs. 2011;25(8).

7. Krummel T, Parvez-Braun L, Frantzen L, Lalanne $\mathrm{H}$, Marcellin L, Hannedouche T, Moulin B. Tenofovir-induced acute renal failure in an HIV patient with normal renal function. Nephrol Dial Transplant. $2011 ; 20(2)$.

8. Kowalak JP, Welsh W. Buku pegangan uji diagnostik. Edisi ke-3. Jakarta: EGC; 2009. hlm. 248-9.

9. Pagana. Mosby's laboratory and diagnostic test reference. Edisi ke-10. Missouri: Elsevier; 2009. hlm 326-8.

10. Gerard L, Chazallon C, Taburet AM, Marie Girard P, Abouljer JP, Piketty C. Renal function in antiretroviral-experienced patients treated with tenofovir disoproxil fumarate associated with atazanavi/ritonavir. Antivir Ther. 2007;12:31-9,

11. Zimmerman AE, Pizzoferrato $T$, Bedford J, Morris A, Hoffman R, Braden G. Tenofovirassociated acute and chronic kidney disease: a Case of Multiple Drug Interactions. Clin Infect Dis. 2006;42:283-90.

12. Doungchalermwong $P$, Sungkanuparph $S$. Use of tenofovir disoproxil fumarate and the monitoring of renal function among HIV-1 infected patients in a resource-limited setting. J Infect Dis Antimicrob Agents. 2010;27:77-84.

13. Markum HMS. Gangguan ginjal akut. Dalam: Sudoyo AW, Setiyohadi B, Alwi I, Simadibrata KM, Setati S, editor. Buku Ajar IImu Penyakit Dalam, Volume ke-3. Interna Publishing: Jakarta; 2009. hlm. 1041.

14. Rodriguez-Novoa S, Labarga $P$, Soriano V, Egan D, Albalater M, Morello J, Cuenca L, GonzalezPardo G, Khoo S, Back D, Owen A. Predictors of kidney tubular dysfunction in hiv-infected treated with tenofovir: a pharmacogenetic study. Clin Infect Dis. 2009;48(11):108-16.

15. Roling J, Schmid H, Fischereder M, Draenert R, Goebel D. HIV-associated renal diseases and highly active antiretroviral therapy-induced nephropathy. Clin Infect Dis. 2006;42:1488-95. 